\title{
PEMBERDAYAAN UMKM BERBASIS EKONOMI KREATIF DI PESISIR PANTAI CIMALAYA - SUBANG JAWA BARAT
}

\author{
In-In Hanidah ${ }^{1}$, Agung Tri Mulyono ${ }^{2}$, Sumanti Debby Moody. ${ }^{1}$, Renita Dwi \\ Aprilani $^{3}$, Imas Siti Setiasih ${ }^{1}$ \\ ${ }^{1}$ Dosen Teknologi Pangan, FTIP - Universitas Padjadjaran \\ ${ }^{2}$ Community Development Officer PHE - ONWJ \\ ${ }^{3}$ Mahasiswa Teknologi Pangan, FTIP - Universitas Padjadjaran \\ *email: inin@unpad.ac.id; pinkyhanidah@yahoo.com
}

\begin{abstract}
Abstrak
Pengembangan UMKM Abon Ikan Tengkek mempunyai peranan yang sangat penting untuk pertumbuhan ekonomi bagi masyarakat Desa Cilamaya Hilir Kabupaten Subang. Penerapan ekonomi kreatif merupakan konsep pengembangan ekonomi pelaku UMKM Abon Ikan Tengkek untuk meningkatkan nilai tambah produk dengan menciptakan produk melalui perbaikan proses produksi, penerapan GMP, perbaikan desain kemasan, peningkatan legalitas usaha, dan perluasan pemasaran. Metode kajian yang dilakukan terdiri dari: observasi, wawancara, persuasif, dan andragogi untuk mengoptimalkan tujuan penelitian. Hasil kajian menunjukkan pemberdayaan UMKM Abon Ikan Tengkek berbasis ekonomi kreatif mampu meningkatkan penjualan sebesar 81,25\%/tahun.
\end{abstract}

Kata Kunci: UMKM, abon, ikan tengkek, ekonomi kreatif

\begin{abstract}
Small and medium-sized enterprises (SMEs) development of "Abon Ikan Tengkek" has a very important role for economic growth for the people of Cilamaya Hilir Village - Subang. The application of the creative economy is the concept businessmen of "Abon Ikan Tengkek" SMEs to increase product added value by creating products through improving production processes, implementing GMP, improving packaging design, improving business legality, and expanding marketing. The method of study conducted consists of: observation, interview, persuasive, and andragogy to optimize the research objectives. The results of the study showed that the empowerment "Abon Ikan Tengkek" SMEs based on creative economy was able to increase sales by $81.25 \% / y e a r$.
\end{abstract}

Keywords: SMEs, abon, tengkek fish, creative economy

\section{PENDAHULUAN}

Ekonomi kreatif adalah istilah yang dikenal sebagai konsep pengembangan ekonomi yang mengandalkan daya kreasi untuk mencitakan produk maupun menambah nilai/value (Pahlevi, 2017). Ekonomi kreatif memiliki potensi besar untuk menjadi salah satu sektor penggerak yang penting untuk mewujudkan Indonesia yang mandiri, maju, adil, dan makmur dengan didasari 3 pilar utama, yaitu: sumber daya alam, sumber warisan budaya, dan sumber daya manusia yang kreatif (Ghazali, 2019).

Secara konsep, manusia, alam, dan kebudayaan merupakan suatu relasi triangulasi kebudayaan yang memiliki keterkaitan satu sama lain (Indrawardana, 2012). Cilamaya Hilir merupakan suatu desa yang terletak di pesisir pantai utara Kabupaten Subang. Desa ini merupakan penghasil padi dan ikan terbesar di Kabupaten Subang karena wilayahnya didominasi pesawahan dan tambak ikan. 
Mata pencaharian penduduk setempat mayoritas sebagai petani dan nelayan. Kurangnya pemahaman pengetahuan menyebabkan pendidikan masyarakat relatif rendah (SD, SMP) lebih memilih menikah dan menjadi ibu rumah tangga.

Banyaknya hasil tangkapan laut, memunculkan ide dari para istri nelayan untuk berkontribusi aktif memanfaatkan hasil tersebut dengan membentuk Kelompok Usaha Wanita (WUB) - Green Think. Tidak sedikit hasil tangkapan laut yang peminatnya kurang dengan harga jual yang relatif murah. Salah satunya adalah ikan tengkek (Caranx crysos) yang merupakan salah satu jenis ikan kuwe, mempunyai nama lain Hardtail Jack, Blue Runner, Runner dan Blue Jack (Tsalis, 2018). Peluang ini dimanfaatkan WUB untuk membuat Usaha Mikro Kecil dan Menengah (UMKM) olahan ikan tengkek menjadi abon ikan.

Negara Indonesia merupakan negara yang kaya akan Sumber Daya Alam (SDA) karena memiliki wilayah daratan dan perairan sangat luas. Pengelolaan SDA yang tepat dapat melaksanakan proses pembangunan secara berkelanjutan dan meningkatkan perokomian masyarakat. UMKM memiliki peranan yang sangat penting karena dapat mempengaruhi dalam pembangunan sosial ekonomi nasional dan dunia (Panga, 2015). Sampai tahun 2015 UMKM telah berkontribusi sebanyak $57,60 \%$ Produk Domestik Bruto (PBD), mempunyai tingkat penyerapan tenaga kerja sekitar $97 \%$ dari seluruh tenaga kerja nasional, dan telah terbukti tidak terpengaruh oleh krisis (Putra, 2016).

Sumber Daya Manusia (SDM) pada UMKM umumnya tingkat pendidikan rendah mulai dari tidak terampil sampai semi-terampil, oleh karena itu sangat penting untuk menciptakan lingkungan yang mendukung mereka untuk belajar dan berkembang (Mwobobia, 2012).

Pendampingan secara berkala melalui pendekatan persuasif mampu memperbaiki sistem proses produksi dan perilaku hidup sehat pemilik UMKM sehingga mampu meningkatkan legalitas usaha (Hanidah, dkk., 2018)

Berdasarkan kajian diatas maka perlu dilakukan kajian mengenai pemberdayaan berbasis ekonomi kreatif terhadap peningkatan kualitas produk dan pendapatan UMKM di pesisir pantai Cilamaya - Subang.

\section{METODE PENELITIAN}

Tahap awal penelitian adalah menentukan UMKM yang menjadi objek kajian dengan cara observasi dan wawancara langsung kepada 10 pelaku UMKM produk olahan ikan di Desa Cilamaya Hilir Kecamatan Blanakan Kabupaten Subang - Jawa Barat. Wawancara meliputi jenis produk, jangka waktu usaha yang telah dilakukan, dan motivasi pelaku usaha untuk mengembangkan usahanya.

Berdasarkan hasil tersebut, maka yang memenuhi syarat sesuai kriteria yang telah ditentukan adalah UMKM "Abon Ikan Tengkek". Pelaku usaha memiliki rekam jejak usaha yang terstruktur, memiliki visi dan misi yang visioner untuk pengembangan usaha baik produk, pemasaran, dan peningkatan legalitas usaha.

Kajian selanjutnya dilakukan metode persuasif untuk meningkatkan motivasi usaha dan metodologi pelatihan andragogi dengan memposisikan pelaku UMKM sebagai orang dewasa dan didorong untuk berperan aktif dalam setiap tahapan pendampingan yang meliputi: GMP, teknologi proses, desain kemasan, 
peningkatan legalitas usaha, dan manajemen pemasaran online.

\section{HASIL DAN PEMBAHASAN}

KUW merupakan Kelompok Usaha Wanita Green Think yang beranggota para istri nelayan dengan dukungan Pertamina Hulu Energi (PHE) ONWJ. UMKM "Abon Ikan Tengkek" memulai usaha dari tahun 2015 dengan memanfaatkan ikan tengkek yang banyak tidak terjual karena memiliki kulit yang keras sehingga harga jual rendah.

Keterbatasan pengetahuan akan teknologi proses menjadikan pemilik UMKM mengolah Abon Ikan secara tradisional dengan kemasan PP yang mudah diperoleh dipasaran dengan harga terjangkau. kemasan plastik polipropilen. Kemasan polipropilen (PP) mempunyai sifat-sifat kimia antara lain: (1) sukar ditembus oleh uap air, (2) tahan terhadap minyak dan lemak, (3) permeabilitas terhadap uap air rendah, (4) stabil pada suhu tinggi, dan mempunyai permukaan yang mengkilat (Hanidah, dkk,. 2018). Namun plastik PP tidak baik digunakan untuk bahan pangan yang mudah rusak oleh oksigen (Julianti \& Nurminah, 2006).

Peningkatan pengetahuan mengenai kemasan terus dilakukan untuk melindungi produk selama proses penjualan agar kualitas produk tetap terjaga dan memiliki umur simpan lebih lama. Pelaku abon ikan tengkek merupakan salah satu UMKM yang Memiliki motivasi besar untuk berkembang. Hal ini sejalan dengan pengembangan usaha berbasis ekonomi kreatif. Perbaikan formulasi dan jenis kemasan terus dilakukan untuk memperbaiki karakteristik sensori abon ikan tengkek (Gambar 1). Sensori rasa merupakan salah satu faktor yang berpengaruh terhadap penerimaan konsumen (Nursiwi, dkk., 2013).

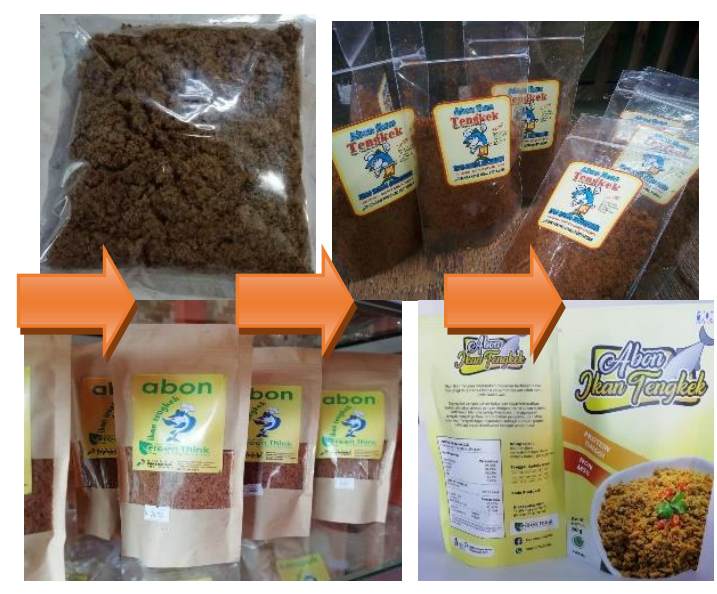

Gambar 1. Perubahan Kemasanan Abon Ikan Tengkek dari Tahun 2015 - 2018

$$
\text { (kiri - kanan) }
$$

Berdasarkan hasil analisis kimia abok ikan tengkek produksi UMKM Cilamaya Subang mengandung 29,38\% karbohidrat, 28,19\% protein, 28,58\% lemak, 4,76\% air, dan 9,09\% abu (per $100 \mathrm{~g}$ sampel). Tingginya kandungan protein dan lemak menyebabkan produk mudah teroksidasi sehingga menimbulkan bau tengik dan rasa yang menyimpang. Hal ini menyebabkan umur simpan abon menjadi lebih pendek. Pemilihan kemasan yang tepat dapat melindungi produk dari cahaya matahari dan reaksi oksidasi.

Alumunium foil merupakan kemasan Abon Ikan Tengkek yang digunakan saat ini (Gambar 1) karena memiliki keunggulan tahan cahaya (tidak bersifat transparan). Kemasan alumunium foil cocok digunakan untuk bahan pangan yang mengandung lemak dan vitamin yang tinggi karena dapat melindungi produk dari cahaya sehingga dapat mencegah terjadinya reaksi kimia dan aktivitas enzim (Julianti \& Nurminah, 2006).

Keberhasilan UMKM dapat dilihat dari minat berwirausaha harus mengedepankan keberanian, mampu bertanggung jawab atas usaha yang dijalankan berani mengambil resiko, mempunyai sikap optimis atas suatu peluang, menciptakan lapangan kerja untuk dirinya sendiri dan bagi orang lain dengan 
jalan berwirausaha untuk mengurangi pengangguran (Nursalina, 2018). UMKM "Abon Ikan Tengkek" dalam proses produksi mempekerjakan para istri nelayan yang berada dalam kelompok WUB Green Think. Berbagai pelatihan dilakukan dengan baik agar mencapai hasil yang optimal untuk perbaikan dan pengembangan produk.

Abon ikan tengkek merupakan produk dengan bahan baku utama ikan, sehingga rentan mengalami kerusakan kualitas karena memiliki kadar air dan kadar nutrisi yang cukup tinggi. Kondisi tersebut merupakan media yang baik untuk pertumbuhan mikroorganisme jika sanitasi dan proses pengolahan dilakukan tidak sesuai dengan standar. Cara produksi pangan yang baik dan benar (CPPB) sangat penting diketahui dan dilaksanakan oleh setiap pelaku usaha pangan agar produk yang dihasilkan aman dan berkualitas sehingga memberikan jaminan keamanan produk bagi konsumen (Hanidah, dkk., 2018).

Pengendalian mutu produk dapat dilakukan dengan penerapan GMP (Good Manufacturing Practice) yang baik. GMP merupakan pedoman cara berproduksi pangan yang bertujuan supaya produsen pangan memenuhi persyaratan yang telah ditentukan untuk menghasilkan produk pangan yang bermutu dan aman dikonsumsi sesuai dengan tuntutan konsumen.

GMP wajib diterapkan oleh industri yang menghasilkan produk pangan sebagai upaya preventif agar pangan yang siap dikonsumsi tersebut bersifat aman, layak, dan berkualitas sehingga konsumen dapat menikmati nilai gizi didalamnya secara maksimal tanpa resiko mengidap penyakit (Ristyanadi \& Hidayati, 2012). Tahapan GMP lebih menitikberatkan terhadap sanitasi selama proses pengolahan baik pekerja maupun alat dan ruang produksi.

Upaya penerapan GMP yang telah dilakukan berupa penyuluhan dan aplikasi langsung mengenai: (1) penentuaan standar kualiatas bahan baku; (2) memperbaiki bangunan tempat produksi; (3) memperbaiki proses pengolahan untuk memperoleh mutu produk akhir lebih baik; (4) aplikasi langsung mengenai hygiene karyawan; (5) membuat layout ruang produksi; dan (6) pemeriksaan laboratorium. Sedangkan parameter pendukung yang dilakukan untuk mencapai ekonomi kreatif meliputi: (1) desain kemasan; (2) penentuan umur simpan, (3) legalitas usaha; (4) manajemen pembukuan; (5) dan pemasaran melalui media online.

Pelaku UMKM diberikan penyuluhan secara bertahap setiap minggu kemudian diberi kesempatan untuk mengimplementasikan hasil penyuluhan. Standar kualitas bahan baku dan forlumasi yang digunakan untuk proses produksi abon ikan tengkek dibuat dokumen khusus agar setiap produk yang dihasilkan masa sekarang dan masa yang akan datang miliki karakteristik sensori dan kuatitas yang sama.

Layout atau tata letak ruang produksi merupakan salah satu faktor penting dalam GMP karena nenentukan alur produksi mulai dari bahan baku masuk sampai produk dihasilkan. Alur produksi yang kurang tepat dapat mempengaruhi kualitas produk karena terjadinya kontaminasi silang mikroorganisme baik dari bahan baku maupun pekerja (Somwang et al., 2013).

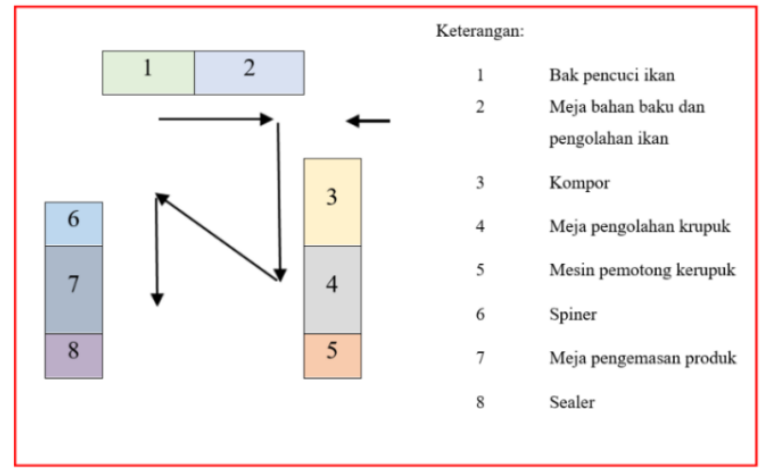

Gambar 2. Tata Letak Ruang Produksi Abon Ikan Tengkek

Pengembangan UMKM mempunyai peranan yang sangat penting untuk pertumbuhan ekonomi bagi masyarakat. Selain berperan 
dalam pertumbuhan ekonomi dan penyerapan tenaga kerja juga berperan dalam pendistribusian hasil - hasil pembangunan. Untuk menjamin UMKM dapat berkembang dengan baik, maka diperlukan strategi pemasaran (Fauzi, 2018). Peningkatan legalitas usaha merupakan salah satu strategi untuk meningkatkan pemasaran.

Peningkatan legalitas usaha produk UKM sangat penting dilakukan sebagai jaminan konsumen bahwa produk yang dikonsumsi aman dan halal. Legalitas usaha suatu produk dapat mempermudah UKM untuk memasarkan produknya ke pasar yang lebih luas. Legalitas usaha untuk Industri Kecil dan Menengah UMKM abon ikan tengkek diperoleh dari Departemen Kesehatan Kabupaten Subang. Sedangkan legalitas Halal diperoleh dari Dinas Koperasi Perindustrin dan Perdagangan (Diskoperindag) Kabupaten Subang. Daya juang yang tinggi dari pelaku usaha sehingga dapat melalui serangkaian pelatihan yang dilaksanakan dinas terkait dengan hasil sempurna dinyatakan lulus.

Legalitas usaha PIRT merupakan jaminan konsumen bahwa produksi Abon Ikan Tengkek sudah sesuai dengan CPPB baik bahan baku yang digunakan, sanitasi ruang produksi, sanitasi pekerja, uji laboratorium, dan informasi label pada kemasan. Hal inilah yang mengantarkan Abon Ikan Tengkek dapat memperluas pemasaran baik secara off-line maupun on-line. Peningkatan jumlah produksi selama 4 tahun (Gambar 3) menjadikan indikator bahwa pemberdayaan UMKM berbasis ekonomi kreatif sangat efektif diterapkankan pada pelaku usaha yang memiliki daya juang dan motivasi untuk mau belajar meningkatkan kualitas produk menuju berkelanjutan usaha.

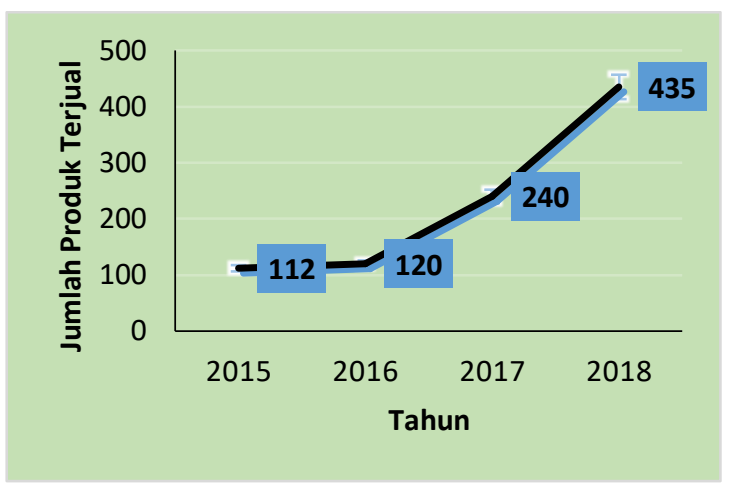

Gambar 3. Jumlah Produk Terjual kurun waktu $2015-2018$

\section{KESIMPULAN}

1. Pemberdayaan UMKM Abon Ikan Tengkek berbasis ekonomi kreatif melalui penerapan GMP, perbaikan kemasan, dan peningkatan legalitas usaha terbukti mampu meningkatkan penjualan sebesar $81,25 \%$.

2. Pengembangan usaha berbasis ekonomi kreatif dapat berhasil jika pelaku usaha memiliki minat berwirausaha, mengedepankan keberanian, mampu bertanggung jawab atas usaha yang dijalankan, berani mengambil resiko, dan mempunyai sikap optimis atas suatu peluang,

\section{UCAPAN TERIMAKASIH}

Ucapan terimakasih dan penghargaan yang tak terhingga disampaikan kepada:

1. PHE - ONWJ melalui Program Pemberdayaan Masyarakat Pesisir Cilamaya Hilir Kabupaten Subang, atas bantuan dana yang diberikan selama kegiatan pengabdian dan penelitian.

2. Program Studi Teknologi Pangan Universitas Padjadjaran, atas semua fasilitas yang diberikan untuk kelancaran kegiatan pengabdian dan penelitian.

\section{DAFTAR PUSTAKA}


Fauzi, I. (2018). Strategi Pengembangan

Usaha Mikro , Kecil Dan Menengah

(UMKM) ( Studi Kasus Pada Ud. Genteng Pres Super Soka Masinal Desa

Pancasan Kecamatan Ajibarang

Kabupaten Banyumas). Skripsi. Institut

Agama Islam Negri (IAIN) Purwokerto.

Ghazali, A. (2019). Ekonomi Kreatif: Rencana Pengembangan Desain Nasional 2015-2019.

Hanidah, I., Mulyono, A. T., Andoyo, R., Mardawati, E., \& Huda, S. (2018).

Penerapan Good Manufacturing Practices Ebagai Upaya Peningkatan Kualitas Produk Olahan Pesisir Eretan Indramayu. Agricore: Jurnal Agribisnis Dan Sosial Ekonomi Pertanian, 3(1), 294-399.

Hanidah, I., Santoso, M. B., Mardawati, E., \& Setiasih, I. S. (2018). Pemberdayaan Pengrajin "Pindang Cue" Desa Jayalaksana Melalui Teknik Pengemasan, 7(1), 14-18.

Indrawardana, I. (2012). Kearifan lokal adat masyarakat sunda dalam hubungan dengan lingkungan alam. Komunitas, $4(1), 1-8$.

Julianti, E., \& Nurminah, M. (2006). Teknologi Pengemasan. (D. T. Pertanian, Ed.) (1st ed.). Sumatera Utara: Universitas Sumatera Utara. Retrieved from file:///D\%7C/E-Learning/Teknologi Pengemasan/Textbook/Kulit Buku Ajar.html (6 of 6)5/8/2007

Mwobobia, F. M. (2012). Empowering of Small -Micro and Medium Enterprises ( SMMEs ): A Case of Botswana. Business and Management Research, 1(4), 88-98. https://doi.org/10.5430/bmr.v1n4p88

Nursalina. (2018). Keberhasilan Usaha Mikro Kecil Berbasis Ekonomi Kreatif Di Kota Makassar. Universitas Negeri Makasar.

Nursiwi, A., Darmadji, P., \& Kanoni, S. (2013). Pengaruh penambahan asap cair terhadap sifat kimia dan sensoris telur asin rasa asap. Jurnal Teknologi Hasil Pertanian, VI(2), 82-89.

Pahlevi, A. S. (2017). Gagasan Tentang Pengembangan Ekonomi Kreatif
Nasional Daya Saing sub sector industry kreatif dan Penyelarasan Industri kreatif kreatif. Prosiding Membangun Tradisi Inovasi Melalui Riset Berbasis Praktik Sedi Dan Desain, 185-188.

Panga, F. P. (2015). Empowering Small And Medium Enterprises (SMES) to Harness Public Procurement Opportunities. International Journal of Economics, Commerce and Management, III(3), 114. Retrieved from http://ijecm.co.uk/

Putra, A. H. (2016). Peran UMKM dalam Pembangunan dan Kesejahteraan Masyarakat Kabupaten Blora.

Ristyanadi, B., \& Hidayati, D. (2012). Kajian Penerapan Good Manufacturing Practice ( GMP ) Di Industri Rajungan Pt . Kelola Mina Laut Madura. AGROINTEK, 6(1), 55-64.

Somwang, C., Charoenchaichana, P., \& Polmade, M. (2013). The Implementation of Good Manufacturing Practices ( GMP ) System in the Poultry Industry: A case study of the hatchery in. International Journal of Humanities and Management Sciences (IJHMS), 1(1), 113-115.

Tsalis, N. (2018). Apa yang anda ketahui tentang Ikan Tengkek? dictio. Retrieved from https://www.dictio.id/t/apa-yang-anda-ket ahui-tentang-ikan-tengkek/ 105768 